\title{
An Analysis on the Effect of Strategic Planning Towards Company Performance in the Effort of Creating Competitive Advantages
}

\author{
Sudjilah \\ Sekolah Tinggi Ilmu Ekonomi Indonesia, (STIE Indonesia) Malang \\ Eny Rachmawati \\ Fakultas Ekonomi Universitas Mayjen Sungkono \\ Adil Abdillah \\ Fakultas Ekonomi Universitas Mayjen Sungkono
}

\begin{abstract}
The purpose of this study is to discover and to analyze the effect of: 1. Managerial factor towards strategic planning, 2. Environmental factor towards strategic planning, 3. Cultural organization factor towards strategic planning, 4. Strategic planning towards the competitive advantages, 5. Company Perfomanc toward Competitive Advantage. This study is a causal type of study and this study tested the results using Path Analysis. The measurement of the result used Linkert scale. The population of this study is the entire Micro-, Small-, Mediumscale Enterprise (UMKM) actors. The data gathered were in the form of primary and secondary data. Study result showed that managerial factor insignificantly and negatively affected Strategic Planning. Then, environmental factor significantly and positively affected Strategic Planning. Cultural organization factor insignificanly and positively affected Strategic Planning. As for managerial factor, it directly influenced company performance. Managerial factor, cultural organization factor, and environmental factor influenced, as many as $63,3 \%$, to Company Performance, whereas managerial factor, cultural organization factor, environmental factor, and performance influenced, as many as $88,8 \%$, to competitive advantage.
\end{abstract}

Keywords: Strategic Planning, Performance, Competitive Advantage

DOI: $10.7176 / \mathrm{EJBM} / 11-35-01$

Publication date: December $31^{\text {st }} 2019$

\section{A. Introduction}

Data from the Ministry of Cooperation and (Micro-, Small-, and Medium-scale Enterprise) UMKM in 2011 stated that more than 55,2 million units of UMKM were able to employ approximately 101,7 million people. These number increased to 57,8 million units of UMKM with employment numbers reaching up to 114 million people. In addition, UMKM has an important role in distributing public economy. UMKM has locations in various places, including areas out of reach from developments. The presence of UMKM in 34 provinces in Indonesia lessened the economic disparity between the rich and the poor. Moreover, UMKM has proven to be able to increase state foreign exchange income, amounting to 88,45 billion rupiah (eight times more than in 2016). The roles of UKM in Indonesia's economy is very strategic, based on the data by the Ministry of Cooperation and Small-, and Medium-scaled Enterprise (UKM) of the Republic of Indonesia, the number of UKM reached 49,84 enterprise units in 2007 , which made up the $97,23 \%$ of the number of national business actors. UKM's contribution to work employments added up to 91.75 millions of people or $97,33 \%$ of the total current work employment, micro-scale enterprises' contribution was recorded to be $92,32 \%$ while medium-scale enterprises' contribution was 5,01\%. UKM's contribution towards the Gross Domestic Product (PDB) in 2007 was $46,96 \%$, where $20,82 \%$ was from from the small-scale enterprise and $26,14 \%$ from the medium-scale enterprise (Statistical data of Indonesia's UKM, 2017.www.depkop.go.id).

The formulation of strategic planning is inseparable from managerial ability. This ability is expressed with managerial competence and supported with the faith of success on the implementation of the strategic planning. No less important, adequate ability in controlling the success of attained goals of strategic planning is underlied with work professionalism. Managerial ability is not merely needed for big companies; small companies also require competent managerial ability.

Good management will promote organization to being able to implement its strategy through program planning, budgeting process, performance management system, organizational structure change, as well as program and project management. Porter (2012:27) in his article titled Competitive Strategy in Harvard Buisiness Review expressed that strategy is a collection of different actions or activities to deliver unique values. While Arthur A. J. (2007:261) stated that strategy consisted of activities full of competitiveness with business approaches to achieve a desireable performance (according to targets). Jackson $(2013: 17)$ in his book titled 
Human Resource Planning: Challenge for Industrial/Organization Psychologists said that the word "strategy" can be used in various ways: 1 . Strategy is a plan, a how a means of getting from here to here. 2. Strategy is a pattern in action over time. 3. Strategy is a position; that is; reflects decisions to offer particular. products or services in particular market. 4. Strategy is a prespective, that is, vision and direction. Referring to these definitions, understanding concerning strategic management was needed. Wheelen \& Hunger (2008:36) explained that strategic management is a series of steps, decisions, and actions of a company to determine its long-term performance.

This was also supported by a study conducted by Routledge Schuler RS (2010:36), which raised his findings, showing there were less than $10 \%$ of formulated strategy that were able to be effectively implemented. It meant that $90 \%$ of companies consistently failed to execture their strategy effectively. Then, Routledge said that $70 \%$ of companies who faced problems, revealed that the real reason was not bad strategy, rather poor execution/implementation. Study result of Peter (2012) discovered that companies can spend approximately US\$ 100 billion for consultation and training for brilliant strategy management. Therefore, strategic management does not only cover formulation process, but also its implementation process.

Next, the development for strategic planning lies at the establishment of sustainable competitive advantage. This can be achieved if management is able to be utilize creation and implement strategy to retain advantages where imitations bound to happen, and to create obstructive factor for a long period of time. (Bharawaj, Varadarajan dan Fahy,1993; Grant,1995; Mahoney dan Pandian,1992; Rumelt,1984, dalam Adinda:2014:81).

Corresponding to the studies by experts in general, it can be concluded that planners defeat non-planners, the logic behind this was the fact that companies who have formal plans are superior to those having informal plans, this was because formulating plans require ideas and goals to be thoroughly considered. (Hopkins and Hopkins,1997; Rue and Ibrahim,1998; Shrader et al.1989,in Adinda:2014:117). This concept was supported by Robinson dan Pearce (1984) quoted by Shrader et al. (1989_116), saying that the more intricate the planning process, the better the performance of an organization. Planning process comprised of three main components (Armstrong, 1982 in Shrader et al, 1989; Robinson and pearce,1984), which are: (1) Formulation, which consists of mission development, main goal decision, internal and external environment assessment, and alternative selection and evaluation; (2) implementation; and (3) management. Factor which influence the success of small businesses are crucial be aware of due to their low level of success. Kirby, 2003 in Endi Sarwoko $(2008: 228)$ in its development, small enterprises face numerous problems. These problems correlated with the lack of entrepreneurship, funding, and market values. Other external factors such as macroeconomic environment, government regulations and policiesm and the availability of physical infrastructures which affect growth. Which is why, it is important to know how these internal and external factors influence the success of small businesses.

\section{B. Literature Review \\ Strategic Planning}

The high level of competitions among companies forced decision makers to conduct detailed research on company culture which consisted of 4 (four) interrelated elements, namely: managerial factor, environmental factor, organizational culture, strategic planning and competitive advantage. Strategic planning emphasized on the importance of forming decisions that placed organization so that it is able to respond to environmental changes. The focus of strategic planning lies on strategic management, which means that the application of strategic thinking on leadership duty of an organization is put into effect to achieve its purposes. Allison, Kaye (2005:81) stated that strategic planning is a systematic process agreed by an organization which accommodate involvements among the main stakeholders, regarding their true priorities for their mission and their responsiveness towards the operation environment. Strategic planning is designed especially to enhance organizational focus, so that all organization sources are optimally used to cater that organization's mission. This means that strategic planning becomes an organization's guideline to become responsive towards a dynamic and unpredictable environment. The process of strategic planning relies on certain managerial resources. Expertise in strategic planning are the knowledge and the competence of the head of organization to carry out strategic planning. The confidence in the relationship between strategic planning and performance is defined as the level of trust by the head of an organization on the possibility that strategic planning can increase organization performance which ultimately create competitive advantage. Planning process consists of three main components (Armstrong, 1982 in Shrader et al, 1989; Robinson and Pearce,1984 in Adinda:2014:54), which are: (1) formulation, which consists of mission development, main goal decision, internal and external environment assessment, and alternative selection and evaluation; (2) implementation; and (3) management. Orpen (1985) stated that planning benefits small companies by encouraging them to seek new alternatives to increase their sales and competitive position. According to Bracker et al (1988:136), he expressed that a well-thought planning will benefit small companies in the rapidly-developing dynamic industries.

Strategic planning often spans a period of one to five years (Matthews \&Scott,1995; Rue \& Ibrahim,1998; 
Robinson and pearce,1997; Shrader et al,1984 dalam Adinda:2014:126). Hence, it can be concluded that strategic planning becomes an organization's guideline to become responsive towards a dynamic and unpredictable environment. Strategic planning emphasized on the importance of forming decisions that placed organization so that it is able to respond to environmental changes.

\section{The Effect of Environmental Factor towards Strategic Planning}

The complexity of environment refers to the diversity and concentration of elements constituting the external environment of an organization. It is important to note that, organization considers a number of differences and element distributions in their environment when formulating strategies. Ansoft (1991) and Moller \& Friesen (1983) in Dave (2007:27) stated that the relationship between environmental changes and strategic planning is strong. This is intended to anticipate uncertain changes and conditions. Complexities of change demands, where the pressure put on to the organization is weak, will result in the lack in intensity of strategic planning processes.

\section{The Effect of Organizational Culture towards Strategic Planning}

When making main changes in the strategy of entering a different phase, the life cycle of an organization will point to problems if it doesn't accumulate organizational culture. How does an organization resolve this problem? In the process of ensuring the harmony between strategy and organizational culture, researchers attempted to develop contingency model in cultural strategic planning. Culture is a metaphorical root of organizational study which is assumed to be an important component.

The definition of organizational culture is described as a crucial part of an organization and as the strategic integration of the concept of culture to the action response towards environmental change. Strategic planning is a management process which develops and manages so that actions can work according to the organization goals, resources, chances, and opportunities in external and internal environment. Hopefully, the changes in environment and economic condition can be managed well through the integration of strategic planning with organizational culture (Porter,1984) in Wirawan (2007:63).

\section{The Effect of Strategic Planning towards Performance}

Henry (1980), Hopkins and Hopkins,(2002) in Abadiyah (2011:89) stated that competence in strategic planning candetermine the degree of relevance of organization to the process of strategic planning. This depends on the level of skill that a manager has in formulating strategic planning. Manager's involvement in strategic planning is due to his/her understanding to affirm that the process is done comprehensively, where the level of attention given depends on whether management has the competency to conduct the process itself.

Miller 1987, and Hopkins and Hopkins, 2002, in Abadiyah (2011:89) explained that there are two main developable variables, which are managerial personality factor, that is the confidence towards the relationships of planning - performance and strategic planning competence. Therefore, the definition focuses on the head of the organization. The relationship between strategic planning and performance is defined as the amount of confidence that a head of organization has in strategic planning in increasing organizational performance, which ultimately leads to competitive advantage.

\section{The Effect of Organizational Performance towards Competitive Advantage}

The purpose of competitive strategy is to achieve sustainable competitive advantage by increasing company performance. Competitive advantage can be achieved by implementing the creation of value strategy, although not simultaneously, but through potential competitor condition (Barney,McWilliam and Turk 1989;Barney,1991) in Dinda (2006:45). According to Barney in Dinda (2006:63), there are 4 (four) qualification essentials for resources and skills in order to be considered as resources for competitive advantages, which are: having values, rare or unique from other companies, its form is difficult to imitate because the product/service is perfect and unsubstitutable with other resources.

In relevance with the effect of company performance towards competitive advantage, this can be achieved if management is able to be utilize creation and implement strategy to retain advantages where imitations bound to happen, and to create obstructive factor for a long period of time.

\section{Research Methodology}

This research is considered quantitative research with causal research type, which aims to identify the causeeffect relationship among variables, and this study seeks to find the genuine type of facts to assist the understanding and predicting such relationship (Ferdinand, 2000 in Abadiyah;2011:91).

The population in this study is the entire sanitair craftsmen that belong to the Micro-, Small-, Medium-scale Enterprise group in Klaseman, Malang. Arikunto (2010:26) expressed, that: population is the whole object of study. If the population number is under 100, then the entire population can be treated as sample. Considering the previous statement, then this study determined samples from the entirety of population, which amounted to 55 people. Data gathered are primary and secondary data. Respondents specifications are owner/manager/worker aged above 20 years old with work experience more than 5 years, comprising of 52 males and 3 females.

Measurement was done using Linkert scale. Sugiyono (2011:36) explained that Linkert Scale is used to measure the attitude, opinion, and perception of an individual or a group of people regarding a social 
phenomenon that is a bipolar continuum scale, where on the leftmost side (low number) describes a negative answer, while the rightmost side (high number) describes a positive answer. Data of the dimension from the analyzed variables in this study which was intended for respondents used a scale from $1-7$ to obtain interval data where scores will be given.

Primary data was collected by using research instrument in the form of question lists where they were distributed to all of the samples. Secondary data was sourced from several available interviewees, among which is the documentations provided by Karang Besuki Sub-district, "Malang dalam Angka", Malang Municipal Central Bureau of Statistics, internet and other relevant sources. The statistical analysis technique in this study used Path Analysis. Path Analysis model was used to analyze the cause-effect relationship patterns among variables to discover both direct and indirect effects from exogenous variables to endogenous variables (Riduwan and Kuncoro, 2011:116). Path Analysis, according to (Riduwan and Kuncoro, 2011:119), is done via correlation and regression, and in its calculation process, a software with SPSS Ver 15 is used. The hypothesis test regarding causality that was developed in the study model was tested using regression coefficient among relationships through $\mathrm{F}$ test and $\mathrm{t}$ test, which are often used in regression. This study was conducted on an even semester from February - April of 2017 in Malang.

The study variables consisted of independent and dependent variables. The naming for path analysis variables differed from correlational analysis naming. In path analysis, exogenous variable (an equivalent of independent variable) and endogenous variable (an equivalent of dependent variable) are used.

\section{Discussions}

1. The first Hypothesis stated that Managerial Variable has a positive correlation with Strategic Planning variable.

The result of statistical calculation in table 5 indicated that Strategic Planning (Y1) can not directly be explained by managerial factor (X1). This finding rejected Hypothesis. It was proven that variable value of strategic planning and managerial factor were negative. As it can not be directly explained due to intervening factor bridging between managerial factor and strategic planning. As proposed by Sudaryanto (2017:156), intervening is a variable between free variable and independent one, resulting in an indirect relationship. The rejection of this hypothesis, based on the writer, is also affected by the educational background of the owner of the industrial business in which $15 \%$ is yunior high school graduates and $20 \%$ high school gradutes. Like the research finding revealing that level of education is closely associated with intellectual growth which is also linked to the increased level of knowledge owned by individuals. Educational background increases intellectual growth, affecting the individual in accepting and reducing the information coming to him. (Sanjaya,2006:227). The higher educational level individual has, the higher knowledge the owner or the employee in sanitair industry of Karang Besuki Malang. In short, the owner and the employees should increase their knowledge by attending educational level he should increase from both formal and informal education which will result in higher competence that will provide optimal contribution in playing their role in their industrial environment. This corresponds to respondents' answers that $00,0 \%$ claimed very strongly disagree with the important role of managerial, 5,5\% claimed strongly disagree, $20 \%$ disagree, 56,4\% agree, $20 \%$ strongly agree and the rest $56,4 \%$ very strongly agree.

2. The second hypothesis stated that Environment variable has a positive correlation with variable of strategic planning. This can be concluded that variable of

Strategic planning (Y1) can directly be explained by environment variable (X2). The result of statistical calculation gained $63,3 \%$ while strategic planning is affected by environmental factor. This hypothesis is acceptable. A company responsive to environmental change has a bigger chance to be adapted to strategic planning. The higher environmental change will enable the company to be adapted to strategic planning. This research finding shows that the precise introduction of the external environmental is vital (Supriyono, 1999;63) because: 1. The number of influential factors remains changed, 2. There are varying impacts, 3 . There is an unpredictable external factor despite the accurate SWOT analysis previously performed, 4. The external condition that was out of the control of the company. (Mahmud Nuhung,2012:64). Another factor showed that environmental condition influences organizational performance including to what extent the organization is involved with the making of the strategies. This shows that environmental and change complexities represent that condition and might be a determinant factor in the strategic planning. (Jumingan,2015:28). This is also supported by the result of questionnaires distributed to respondents that organizational environment influences strategic planning which accounted for $0 \%$ claiming very strongly disagree, 12,7 strongly disagree, $9.1 \%$ disagree, 47,3\% agree, 21,8 strongly agree and 9,1\% very strongly agree. To conclude, the hypothesis is accepted.

3. The third hypothesis stated that Organizational culture has a positive correlation with strategic planning.

Based on statistical examination, it has an insignificant and positive influence. It can be concluded that Strategic Planning (Y1) can not directly be explained by Organizational culture (X3) due to moderating factor which 
influences. Moderating factor is a variable influencing the direct relation between independent and dependent variabes. It indicates that organizational culture is not the single factor affecting strategic planning. The research finding sourced from primary data collection regarding the influence of organizational culture having a positive influence on strategic planning indicated that $29 \%$ respondents highly strongly disagreed, $2 \%$ strongly disagreed, $2 \%$ disagreed, $29 \%$ agreed, $22 \%$ strongly agreed and the rest $29 \%$ very strongly agreed despite an insignificant result. Referring to those responses, it shows that most of the primary sources stated their disagreement toward organizational culture. Research by Endi Sarwoko (2008:236) stated that organizational culture is more concerned about employee's engagement in the making of strategic planning so that in the future the business owner will be concerned about this issue. The employee engagement will create strong organizatiomal culture, resulting in strategic planning. Mudrajad (2016:252) claimed that employee involvement in the formulation of strategy can increase the employee motivation. Bottom up policy is more precisely implicated than top down policy.

4. The fourth hypothesis stated that strategic planning has a positive correlation with organizational performance. Based on the statistical calculation result of the effect of Managerial Factor variable (X1) towards Strategic Planning variable (Y1), the tcalculated is shown to be $-0,074$, p-value is shown to be 0,941 and path coefficient (beta) value is shown to be $-0,009$. T test result displayed that the value of tcalculated is smaller than the value of ttable $(-0,074<1,675)$. Stated at the table, the p-value is larger than the significance value $(0,945<0,05)$. If the value of tcalculated is smaller than the value of ttable, and the p-value is larger than the significance value of 0,05 , while the path coefficient (beta) is negative, then the result of this effect is not significant and negative. Thus, it can be concluded that the Strategic Planning variable (Y1) can't be directly explained by managerial factor (X1).

The result of statistical calculation of organizational Culture variable (X3) toward variable of Organizational competence (Y3) indicated that tcalculated is shown to be 0,498 , p-value is shown to be 0,621 and path coeeficient (beta) is shown to be 0,396 . T test result displayed that the value of of tcalculated is smaller that the value of ttabel $(0,498<1,675)$. Stated at the table, $p$-value is smaller than the significance value $(0,222>0,05)$. If the value of tcalculation is smaller than that of ttabls and p-value is higher than that of its significance value of 0,05 , and path coefficient (beta) is positive, then the result of this effect is positive, resulting in insignificant and positive. This can be concluded that variable of strategic planning (Y3) can not directly be explained by variable of organizational performance (X3). According to the writer, this is affected by quality of human resorce which acts as the company manager. Davidsson (1991) found that industrial experience, managerial and entrepreneurial skills of the owner/manager together with external factors provide positive contribution in the success of micro scale business operation. Hashim, Wifa, dan Suliman (1999) have proven empirically that the characteristics of entrepreneurship of the owners / managers are closely related to the success of the company. O'Regan et al (2006) maintained that ownership is a key factor of business performance in a whole. The overall research result of Zoysa dan Herath (2007) indicated the mental relation of owner/manager with performance in the stage of business development showing that in the stage of decline, if the owner/manager of SMEs is more entrepreneurial minded, it will result in higher performance. During maturity growth, if owner/manager is administrative minded then the performance will be higher. This means that the precise strategic planning will influence company's performance. However, when this research was conducted, the result was not significant which means that there was still another influencing factor. It means that the precise strategic planning will influence the performance. This analysis is suited with research by Endi Sarwoko (2008:235) who found that the characteristic of the owners in small and medium scale industries became the factor in determining the business strategies which will be undertaken. Then business strategy will also influence the success of the business significantly. The higher risk he takes, the higher innovative capacity, ambition, imagination and the level of aggresiveness and confidence will result in the higher capacity of performing both internal and external environmental analysis (business strategy) which, in turn, leads to business success gains. This finding is even strengthened by research conducted by Routledge Schuler RS (2010), who stated that less than $10 \%$ strategy which was formulated can be effectively implemented. It means that $90 \%$ of the companies consistently failed to execute its strategies effectively. Also, Routgledge argued that $70 \%$ of the companies encountering problems has poor implementation instead of poor strategies.

5. The fifth hypothesis stated that Company performance has a positive correlation with competitive benefit.

The result of statistical computation of the effect of competitive gain variable (Y2) on variavle of company performance (Y3) showed that tcalculation is known to have 1,613 , the p-value is 0,113 , path coefficient (beta) is known to have 1,613. The result of $t$ examination indicated that the value of tcalculation is smaller than that of ttable $(1,613<1,675)$. P-value is smaller than significance value $(0,113>0,05)$. If the value of tcalculation is smaller than that of ttable and p-value is higher than significance value of 0,05 , and coefficien path (beta) is positive, the the result of this effect is insignificant and positive. From this result, it can be concluded that the company performance (Y3) can not be directly explained by competitive gain (Y2). Understanding this finding, the writer finds a different phenomenon from the general one. If the performance is increased, it will result in the 
increased competitive benefit. Yet, the result is insignificant. It means, according to the writer, that it is an actualization of one of the obstacles in the management of small scale industry. As seen from the research field by the writer that: 1 . In general, the owner of small scale industries feel no need to perform feasibility study, market research and the analysis of cash flow. 2. They only do short-term planning. 3. Work system is only based on intuition and the owners' ambition. 4. There is lacking of implementation instructions and low quality control of work outputs. 5. Disproportional work distribution. 6. Problem of finance 7. Too many stocks resulting in out of date models. 8. Lack of attention from the manager toward the management. 9. Risk and debts and receivables are only the responsibilities of the manager. 10. Business continuity depends on the manager who may sometimes suffer from sickness or even death. 11. Limited capital resources by the owner. This was described by Endi Sarwoko (2008: 4) that industrial, managerial, and entrepreneurial experience of the owner / manager, together with several external factors, contribute positively to the success of small business operations. The results of the overall research of Zoysa and Herath (2007) showed that there is a relationship between mental state of owner / manager and performance at different stages of business growth, the results show that at the decline stage, if the owner / manager of SMEs is more entrepreneurial minded, the performance will be higher. During growth / maturity stage, if the owner / manager is administrative minded then the performance will be higher. Furthermore, a study conducted by Rahayu Puji Suci showed that entrepreneurial orientation had a positive and significant effect on the management ability of an entrepreneur in small and medium industries in East Java. In this study there are 4 (four) important things that must be considered by an entrepreneur in order to have good management skills. In the first place, he must have the desire to achieve strong goals. Secondly, he must have confidence and description of the level of success that can be achieved from a business. Thirdly, he must also have high confidence in every action and decision he makes. And Fourth, he must have the openness especially related to the surrounding environment. In short, the entrepreneurial orientation encourages entrepreneurs to carry out activities in the management process such as business planning through opportunity identification, organizing and staffing through the collection of human resources, directing and coordinating through the implementation of production or trading processes and evaluations related to minimizing business risks in the future. Entrepreneurial orientation and management capabilities synergize either intentionally or not through innovation and creative ideas in which entrepreneurs embody and carry out to achieve profitable business performance. There is an indirect relationship, namely Strategic Planning affecting the performance of companies through competitive advantage which means that by continually reviewing and evaluating strategic plans / strategic planning that have been carried out, the company is able to provide higher quality products and performance to consumers so that it can improve company performance, namely operational performance where the company is able to meet customer needs. Strategic Planning influences the performance of the company through competitive advantage. This condition means that competitive advantage is a good intervening variable where strategic planning can improve company performance through increasing competitive advantage.

\section{E. Conclusiom}

Based on the data analysis and the discussion, it can be concluded that:

1 Hypothesis one stated that: Manajerial variable has a positive correlation with strategic planning variable. Strategic planning can not directly be explained by managerial factor. This finding rejects the hypothesis. It was proven that the value of strategic planning and managerial factor is negative. As it can not directly be explained, it occurs due to intervening factor, bridging between managerial factor and strategic planning which is the educational background factor of the owners in which $15 \%$ is a yunior high school graduates and $20 \%$ is High school graduates.

2. Hypothesis two stated that: environmental variable influences strategic planning variable. Environmental variable has a positive influence on strategic planning. Strategic Planning can directly be explained by environmental variable. This hypothesis is acceptable. A company responsive to environmental change from both internal and external factors has a bigger chance to be adapted to strategic planning.

3. The higher environmental change allows the company to balance to be more adapted to strategic planning adjustment.

4. Hypothesis three stated that: organizational culture is more concerned about employees engagement in the making of strategic planning so that in the future the business owner will be concerned about this issue. The employee engagement will create strong organizatiomal culture, resulting in strategic planning. Mudrajad (2016:252) claimed that employee involvement in the formulation of strategy can increase the employee motivation. Bottom up policy is more precisely implicated than top down policy.

5. Organizational Culture has a positive impact on Strategic planning. Based on the result of the analysis, this effect is not significant and positive. To conclude, the analysis result rejected the hypothesis. This is because Strategic planning can not be directly explained by organizational culture. There is a moderating factor influencing the employee involvement in the making of strategic planning which is motivation, so that the business owner will be more concerned about the employee engagement that will create strong organizational 
culture to create strategic planning. The policy of bottom up is more implicated than top down policy

6. Hypotesis four stated that: Strategic planning has a positive effect on the organizational performance. This analysis shows that variable of strategic planning can not be directly explained by variable of organizational performance. According to the author, this is influenced by the quality of human resorce which also acts a company manager. Several experiences from the industry, managerial and entrepreneurial skills of the manager / owner together with the external factors provides positive contribution to the operation of smallscale industries. Empirically, the characteristics of of the entrepreneurial skills of the managers are closely linked to the company businesses. Ownership is a key factor of business performance in a whole. This means that the precise strategic planning will influence the company performance. Yet, when the research was conducted, the result was not significant. As there is another influencing factor. The characteristic of the owners in small and medium scale industries became the factor in determining the business strategies which will be undertaken. Then business strategy will also influence the success of the business significantly. The higher risk he takes, the higher innovative capacity, ambition, imagination and the level of aggresiveness and confidence will result in the higher capacity of performing both internal and external environmental analysis (business strategy) which, in turn, leads to business success gains. It means that Less than $10 \%$ strategy which was formulated can be effectively implemented. It means that $90 \%$ of the companies consistently failed to execute its strategies effectively. Also, $70 \%$ of the companies encountering problems has poor implementation instead of poor strategies.

7. Hypothesis five stated that the organizational performance has a positive effect on the competitive benefit. The result showed that competitive benefit has insignificant and positife effect. It can also be concluded that company performance can not be directly explained by competitive benefit. If the performance is increased, it will result in increased competitive benefit. Yet, the result was insignificant due to several obstacles in managing small scale industry.This reveals that competitive benefit is a good intervening variable in which strategic planning is able to enhance the company performance through the increased competitive benefit.

\section{Input}

The formal education limitations of the sanitair craftsmen at Karang Besuki Malang can be overcame through informal or non-formal education. An analysis on the dynamics of both internal and external company environments (SWOT analysis) indicated that both company's threats and opportunities needed to be resolved and catered, respectively. The efficiency used as the standard of organizational performance must be complemented with adaptability or the openness to environmental changes in order to increase performance through competitive advantage. The company needs to intensify its motivation to the employees so that their performance can increase. Apart from that, it is compulsory to refine the owner's entrepreneurship ability in order to build a stronger durability to overcome the oncoming changes. The ability to create or make products, which have its own distinct characteristics (product differentiation) that differs with other sanitair products from other regions where it can become an unsubstitutable product, should become the main focus because Indonesia has entered the free market era. Attention from the regional government in the empowerment of UMKM on the Sanitair industry at Karang Besuki Malang is needed. Also, awareness from academicians is also needed in order to further empower the businesses on Sanitair Industry at Karang Besuki Malang, where it also serves as the place for scientific applications given in academic environment.

\section{Study Limitation}

In its process, this study had several limitations, which were: The number of population/samples obtained during this study can only fulfill the minimal sample. There is a possibility that this can affect the result findings which were able to be collected for this study. However, this study had to potray the sample condition as it was, which means the observation may not be similar to the theoretical and empirical researches used as the analysis in this study. UMKM actors had not fully understand the importance of strategic planning for the interests of the company in the future. Their mindset was too traditional and less responsive with all the changes that will always happen.

\section{References}

Abadiyah,Rofidah,2013. Prosiding Call for Paper 2013 : Bidang Manajemen. Fakultas Ekonomi Universitas Muhammadiyah Sidoarjo, Jl. Raya Gelam 250 Candi Sidoarjo

Arikunto,Suharsimi.2010.Prosedur Penelitian Suatu Pendekatan Praktik.Penerbit Rineka Cipta.Yogyakarta.

Barker III, V. I. and I. M. Duhane (1997). "Strategic Change in the Turnarround Procces: Theory and Empirical Evidence. Strategic Management Journal 18: pp. 13-138.

Chen,L.Y. 2014. "Examining the effect of Organization Culture and Leadership Behaviors on Organizational Commitment,Job Satisfaction, and Job performance at Small and Middle-sized Firms of Taiwan "The Journal of American Academy of Business" (September 2014): pp. 432-438.

Ciputra.2009.Ciputra Quontum Leap;Entrepreneurship Mengubah Masa Depan Bangsa Dan Masa Depan Anda.Elex Media Komputindo.Jakarta.

Dave.2007.A Career Advising analysis of the motivations and personalities of highly succesfull woman business 
owner.advansing women in leadership on-line journal.winter.

Dewi, Nomastuti.J 2015. Analisis Pengaruh Budaya dan Lingkungan Organisasi terhadap Konsensus Strategi dalam Rangka Meningkatkan Kinerja Organisasi. Penelitian. April

Endi.Sarwoko.2008.Kajian Faktor-Faktor Yang berpengaruh Terhadap Small Bisnis.jurnal Modernisasi Volume 4 nomor 3, Oktober 2008, halaman 236 - 237.

Ghozali,Imam. 2014. Model Persamaan Struktural. Konsep \&Aplikasi dengan Program Amos ver.5.0. Badan Penerbit Universitas Diponegoro. Semarang

Jumingan,right Issue,.Faktor-faktor tang mempengaruhi Perencanaan Strategik.Jurnal Bisnis \& ManajemenVol. 15 , No. 2, $2015: 23-48$

Maharani,Dinda Estika 2014.Analisis Pengaruh Perencanaan Strategis Terhadap Kinerja Perusahaan Dalam Upaya Menciptakan Keunggulan Bersaing.

Nuhung,Mahmud.2012. JEB Jurnal Ekonomi Balance Volume 8 No. 1 Juni 2012.hal.64.

Porter E.Mikhael.2012. the five competitive forces that shape strategy.Competitive Strategy.Harvard Buisiness Review.Januari

Rue,L.W, Ibrahim,N.A.(1998). "The Ralationship between Planning ophistication and Performance in Small Businesses" Journal of Small Business Managment" October 1998, pp.24-32.

Priscilla Natasha dan Devie. Pengaruh Strategic Planning Terhadap Keunggulan Bersaing Dan Kinerja Perusahaan. 186 Business Accounting Review, Vol. 1, No.2, 2013

Rahayu Puji Suci: Peningkatan Kinerja Melalui Orientasi Kewirausahaan, Kemampuan Manajemen, dan Strategi Bisnis. Fakultas Ekonomi, Universitas Widyagama Jl. Borobudur 12 \& 35, Malang.

Riduwan dan Kuncoro.2011, Cara Menggunakan dan Memaknai Analisis Jalur (Path Analysis) oleh Riduwan, Engkos Achmad Kuncoro.Penerbit Alfabeta.Bandung.

Sanjaya,Toni.2006.kajian model empiris perilaku berwirausaha UKM DIY dan Jawa Tengah. Jurnal Manajemen dan Kewirausahaan. Ol. 10 No. 2, September 2008:93 - 104

Shrader,C.B, Mulford,C.L, Blackburn,V.L 1989. "Strategic and Operational Planning Uncertainty, and Performance In Small Firms "Journal of Small Business Management” October 1989, pp.45-60

Sugiyono.2011.metode penelitian kuantitatif, kualitataif, dan R\&D.penerbit CV Alfabeta.Bandung.

Syafar,A.W. 2014. "Membangun Daya Saing Daerah melalui Kompetensi Khas (Distinctive Competence) Berbasis Komoditi Unggulan” Usahawan - No 03, TH XXXIII - Maret, hlm.3-11.

Wheelen Thomas L., dan David Hunger J. 2010, Strategic Management and Bussinesss Policy, Fourth Edition, Achieving Sustainability, 12 th Edition.Pearson Prentice Hall Upper Sadle River (New York: Addison Wesley Publishing Company).New Jersey.

Wirawan. 2009. Evaluasi Kinerja Sumber Daya Manusia (Teori Aplikasi dan Penelitian). Jakarta: Salemba Empat 